\title{
On Race and Modern Architecture
}

\section{Diane Ghirardo}

\section{Book Review / CROSS-DISCIPLINARY STUDIES}

\section{Race and Modern Architecture. A Critical History from the Enlightenment to the Present} By Irene Cheng, Charles L. Davis II, and Mabel O. Wilson, eds Pittsburgh PA, USA: University of Pittsburgh Press, 2020 $7 \times 10$ in. $[17,8 \times 25,4 \mathrm{~cm}]$ 96 b\&w illustrations 424 pages

$\$ 45$ paperback July, 2020

ISBN: 978-082 2966593

\section{Building Character. The Racial Politics of Modern Architectural Style By Charles L. Davis II Pittsburg PA, USA: University of Pittsburgh Press, 2019 \\ $7 \times 10$ in. $[17,8 \times 25,4 \mathrm{~cm}]$ $89 \mathrm{~b} \&$ w illustrations, 12 color plates 320 pages $\$ 55$ hardcover December, 2019} ISBN: 978-0822945550
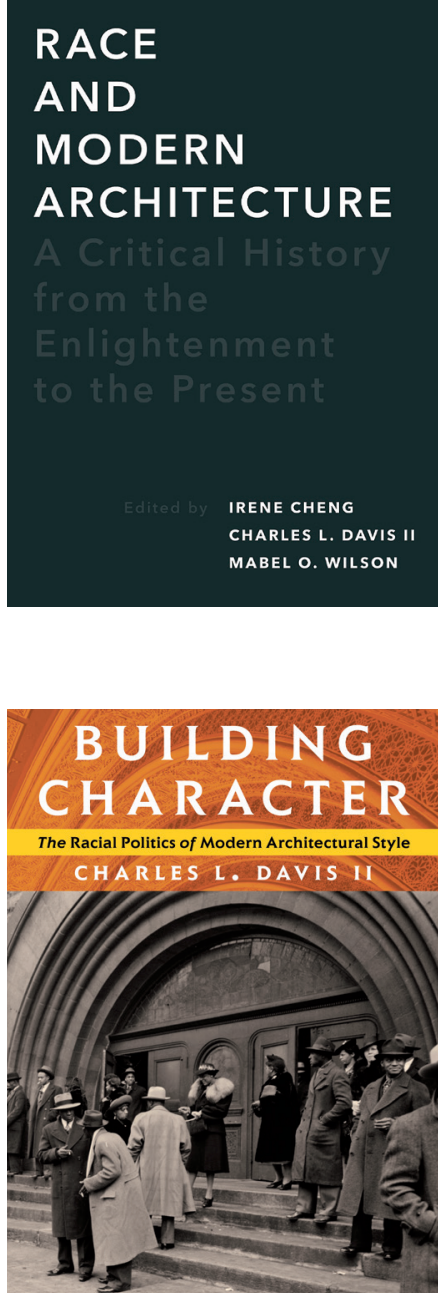

As the streets of cities across the globe filled with people protesting the killing of George Floyd in Minneapolis, Minnesota, the volume Race and Modern Architecture (2020) appeared. It could hardly have come at a more appropriate time, as discussions of systemic racism in the United States 
spread from the classroom to the streets, from the streets to the halls of government. This book, and the earlier one by Charles Davis also about race and modern architecture, Building Character (2019), draw attention to the longstanding unwillingness of professionals and academics to engage questions of race in architecture.

In part, this has entailed ignoring the work produced by architects of color. When my institution elected to host a small exhibit on the work of the school's first and most significant Black architect, Paul Williams, it did so in the underground library, hardly a site likely to encourage visitors. But he is not alone: the architect of many stunning buildings on the campus of Duke University, Julian Abele, as a black man could not have enrolled there. Even more obscure are female architects of color, such as Norma Sklarek, Tatiana Bilbao, Fernanda Canales, and more. How many students learn about "any" female or BIPOC architects in their architecture classes? Somehow, few instructors seem able to identify work by women and BIPOC architects as precedents to study or as engaging important issues.

Apart from the absence of BIPOC architects from classrooms and as exemplars of fine design, there are broader issues to consider with regard to race and architecture, issues explored in these two new books. Charles Davis' Building Character takes on the late nineteenth, early twentieth century organicism movement within modern architecture. In part Davis unpacks some of the assumptions about the presumed universal character of modernism, and in part he exposes the racist and racial assumptions in the writings and practice of key figures in the modern movement, from Viollet-le-Duc to William Lescaze. Davis argues that beneath the apparently neutral facade of discourses about ornament lies a set of assumptions about race, progress, racist principles in contemporary sociology and ethnography. Scholars familiar with Eugène Viollet-le-Duc and Gottfried Semper will not be surprised at the evidence Davis collects, but what is new are the subtle, nuanced and provocative arguments he makes that go well beyond previous scholarship on race in the work of the two nineteenth century theorists. More surprising is his inclusion of Louis Sullivan and William Lescaze, two figures not usually associated with the ideas of the earlier duo.

As Davis points out in his introduction, he is challenging the assumption prevalent in the writings of Nicholas Pevsner and Erwin Panofsky, among others, about the transparency of cultural thought in architecture, with ornament as the key factor until the second half of the twentieth century. As he demonstrates, race and style became the two pillars of the arguments on behalf of an organic approach to ornamentation. For Davis the significance of the racial dimensions underlying ornament and modern architecture go well beyond the simple analysis of ornament itself; instead, he explores the largely hidden cultural associations that were understood as normative at the time. One of the distinct contributions that 
Davis makes emerges in his arguments about the persistence of racial and nationalist assumptions in the very spatial and structural figuration of modern architecture. This may well be the most contested dimension of his study, but for that very reason, it is also perhaps one of the most important. A second highly original contribution here are the chapters on Sullivan and Lescaze. In both cases his arguments are nuanced, thoughtful and innovative.

Davis goes well beyond simply studying a style or an ornament, instead seeking to position his discussion within a much larger cultural and political context. Race, he also demonstrates, is a concept that extends well beyond the color of someone's skin; it embraces a range of characteristics supposedly associated with a particular race. To the point, he includes discussions of the reception of Irish, Italian and Jewish immigrants, and how an architect such as Sullivan tried to make his own nationalist interests cohere with the quite different expectations of these client groups.

The author's exploration of these subjects in the book is beautifully argued, elegantly written, and extremely provocative. It is based on wide reading, careful archival research, and a great deal of reflection well outside of the ordinary contours of architectural history. I cannot help but wonder just how much attention the very white world of architectural history will actually give to this work, unsettling as it may well be for many scholars. Yet it should be used as an exemplar, one that could open up discussions about more recent architectural discourses and historical approaches - not to mention pedagogy. Davis gives a tantalizing preview of a critique of contemporary architectural production in the conclusion, where his analysis expands to consider architects such as Frank Lloyd Wright and Wallace K. Harrison. The analysis certainly offers many possibilities and is no doubt likely to put many contemporary architects on the defensive.

Race and Modern Architecture assembles eighteen essays that span the globe, from Lagos to Los Angeles, Detroit to Mexico City, and engage the issue of race in many different ways. The book is subdivided into six sections: race and the enlightenment, race and organicism, race and nationalism, race and representation, race and colonialism, race and urbanism. Unusually, the essays are equally strong, based upon significant archival and on-the-ground scholarship, with vigorous, fresh arguments. The result of a multi-year collaboration, the stated goal of the authors is to 'write race back into architectural history.' The focus of the enterprise is the architectural history and theory of European and North American scholarship.

In the first group, Mabel Wilson, Peter Minosh, Reinhold Martin, and Addison Godel discussions center on the relationship between slavery, enlightenment, and empire. Wilson and Minosh explore some of the racial dimensions of the early United States. Wilson's study of Thomas Jefferson's projects, from his house to the University of Virginia to the state's capitol, traces the persistence of his deeply held racism over time. She considers 
the views of Enlightenment thinkers that Jefferson shared, including the noxious racism of Emmanuel Kant, among others. As she so beautifully demonstrates, Jefferson's architecture parallels his racist essays, where he painstakingly disparaged the accomplishments of Black Americans at the time, such as Ignatius Sancho and Phillis Wheatley. Minosh reveals the role of slaves in the project for the US capitol as designed by William Thornton, a structure that depended almost entirely on slave labor, whether the actual construction or the financial resources that made it possible. As an abolitionist, Thornton attempted to return former slaves to Africa, in Granville Town. The idea was that this society would participate in the EuroAmerican economic system while rejecting slave labor. The failed venture was nonetheless suggestive of a proposal to institute moderate changes, to enact reform to avoid a much feared revolution.

The Enlightenment itself, and its progeny up to and including the theories of Michel Foucault, is the subject of Reinhold Martin's astute contribution. It is to Jefferson, again, that Martin turns in the first part of his essay, for the careful use and obscuring of slaves and slave labor is painfully clear in Monticello. Ranging from Manfredo Tafuri to Lewis Mumford, Martin exposes the often hidden racist assumptions or, perhaps better, blindness to which they and many others subscribed. Mumford was involved with the development of the NAACP, but his blindness, like that of Tafuri, to the racist foundations of the architecture and ideas of Jefferson is striking. Mumford countered the emerging emphasis on race with the argument that civilization was battling the emergence of pan-national racism, which he saw as dangerous - a perspective no doubt due to the vile nationalism of Nazi Germany, among others. In espousing such a framework, he ended up silent about, and indeed, silencing, racism as it surfaced and flourished all around him.

Addison Godel's essay traces the changing assessments of Chinese gardens, from the early Jesuit visitors to the Anglo-French armed forces who destroyed the extraordinary 800 acre imperial garden in 1860, as an assertion of Britain and French imperial pretensions and racial superiority. This is perhaps most memorably evinced in Sir Bannister Fletcher's 'tree of architecture' in his A History of Architecture on the Comparative Method (1896), where Chinese architecture does not even appear.

Charles Davis' chapter on Henry Van Brunt consists of a penetrating analysis similar to those conducted in his book, once again presenting a nuanced account of Van Brunt's embrace of the racial roots of vernacular architecture as United States settlers and armies marched west across the continent. Joanna Salisbury sets out from P. B. Wight's National Academy of Design building in New York, and the 1865 exhibit where one of the most discussed exhibits was sculptor Anne Whitney's semi-nude Black female representing Ethiopia, in celebration of the coming freedom of Africans from slavery. As she demonstrates, the building's neo-Gothic style itself was meant to express abolitionist values and in particular, the Ruskinian notion 
of Gothic architecture's craftsmanship countering industrial production and the diminution of craft labor. In the United States, the concept of "free labor, free soil" indicated precisely that.

The Davis, Martin, and Wilson essays also serve as background for Irene Cheng's contribution, in which she exposes the deeply racist, white supremacist origins of modern architecture. In the seamless transition from the Enlightenment that emerged in the nineteenth century, architects and theorists sought laws of historical change to explain how societies change, in the process utilizing classification models from the biological and geological sciences. Evolution in architecture in turn came to be linked with what was understood as racial and cultural evolution. Naturally, the West stood at the apex of that evolutionary process. Cheng demonstrated the way studies of typology inexorably linked building types and ornaments with racial characteristics, emerging into full view with the international exhibitions with their "primitive" housing exemplars and even in Adolf Loos' essay, "Ornament and Crime" (1910; publ. 1913). The putative triumph of modernism effectively subsumed race within a western discourse of the triumph of a universal model of architecture, where race remained present but concealed.

Three chapters treat the relationship among vernacular, colonial, and modernist architecture. Luis Carranza's nuanced, richly researched chapter moves from the US and Europe to explore the role of race in Mexico's nascent nationalism in the early twentieth century, when race was understood not only as biological traits, but also as culture and class. Theorists and architects deliberately sought to recover and celebrate indigenous architectural traditions, as distinct from those of the colonial period, even while governments such as that of Porfirio Díaz brutalized the same indigenous population. A second approach, proposed by architects such as Jésus Acevedo and Federico Mariscal, was to celebrate mixing vernacular and colonial traditions to achieve an authentic, autochthonous, architecture. By the 1950s, this aspiration for Mexican architecture played a significant role in the country's burgeoning nationalism. Once Mussolini's government defined Italy as an imperial power after adding Ethiopia to its colonial holdings in Africa in 1936, the previously desultory emphases on Italian race hardened into an explicitly racist policy. In this Fascist fantasy, Italians were a special group of Aryans, a branch that originated in ancient Rome and remained uncontaminated since. Brian McLaren elegantly traces the explosion of racism in Italy from the 1920s to the 1930s, as many architects began to disparage modernist architecture as Jewish, foreign, non-Italian. Marcello Piacentini, perhaps the most powerful and well-connected architect, explicitly summoned race as one of the factors that determined a genuine vernacular architecture that sprang from Italy's millennial traditions. When the League of Nations instituted its sanctions in 1936, autarchy in the use of building materials became a new standard of Italianness. McLaren carefully demonstrates this in the sequence of 
designs by Mario de Renzi and Gino Pollini for the competition for the piazza delle Forze Armate and its buildings in 1938.

Germany's vernacular, or indigenous architecture, is the subject of Kenny Cupers' chapter, where he traces the growing focus on race in architecture particularly in the Heimatschutz (homeland protection) movement.

One aspect of late nineteenth century nationalism was the search for Lebensraum (living space), the expansion of German settlements in Poland and in newly acquired African colonies. Invented traditions and notions of Aryan purity and superiority underlay the extermination of native Africans in Namibia, and the insertion of "traditional" German architecture as replacement - presaging the horrors of a few decades later. Adrienne Brown and Dianne Harris address the representation of race in photographic campaigns in the United States. Brown explores the representations of race in William Starrett's 1928 richly illustrated book on skyscrapers, where the author proudly cites the Anglo-American pedigree of the architects of the earliest skyscrapers, effectively ignoring the immigrant, Native American, and Black laborers who actually built them not only in the text, but in the images. Dianne Harris instead illustrates the ideal of white domesticity of the 1950s in the widely celebrated model homes of the future in U.S. Gypsum's Research Village (1955) in houses designed by architects such as A. Quincy Jones and Hugh Stubbins, among others. Where magazines usually published architecture without people, for Research Village the photographs included abundant scenes of families artfully disposed in ideal homes - always white. Such images not only documented the architecture, they served as settings for advertising campaigns by building supply companies. The same year, another photograph, this one of the battered body of Emmet Till, countered the reality of the brutality inflicted on Black bodies with the untroubled and tranquil white bodies ensconced in America's growing suburbs.

Three chapters shift the discussion to colonial settings in southeast Asia and Africa. The nationalist emphasis on an architecture of Malay identity in Singapore and Malaysia is the subject of Jiat-Hwee Chang's chapter, where British and Chinese traditions inform the efforts to shape an identifiable Malay architecture in part through the invention of a "tropical architecture" most responsive to climate concerns. The partitioned world of the colonial subject described by Franz Fanon sets the stage for Mark Crinson's study of the issue particularly in Kenya. Decongesting cities by shifting people to 800 new rural villages underlay British attempts to combat communism and to control an increasingly restive native population. A composite, even volatile, mix of Black Europeans, Black immigrants from South America, various Native groups, Muslims, Christians, and indigenous religions characterized late nineteenth century Lagos, Nigeria, as Adedoyin Teriba demonstrated in his study. The architecture created by and for each group at once expressed and occluded different traditions and participated in a similar search for an autochthonous architecture. 
The final three chapters directly address recent examples of race and urbanism. Andrew Herscher's penetrating account of the recent history of "blight," the racist determination that some parts of cities need to be cleared (much like so-called "slum removal" and "urban renewal" in earlier periods) because as in Detroit, they are 'blighted.' The most recent campaign, powered by the billionaire founder of Quicken Loans Dan Gilbert, targeted some 80,000 houses - mostly occupied by Black families - for removal. Herscher describes resistance, but he also persuasively argues that such "blight" does more than exemplify degradation; instead, it plays a key role in the US capitalist economy in that such areas help maintain an underemployed, underpaid labor force to be exploited when convenient for capital. The poverty and exploitation of Watts, in south central Los Angeles, led to the rebellion of 1965, one of the key triggers for white flight from east to west Los Angeles. From the devastation wrought by centuries of oppression and exploitation, artist Noah Purifoy assembled remnants of the rebellion, fashioning bits and pieces of flotsam and jetsam, into compelling works of art displayed at UCLA. Lisa Uddin describes Purifoy's art as "junk modernism," something he came to after being unable to establish a career as a designer after his graduation from Chouinard Art Academy. Blacks and Latinos found it almost impossible to break into these industries, almost at all levels, in Southern California in the 1960s, so Purifoy and a friend worked together as designers within the Black community. Uddin's study celebrates his work, positioning it within the racist crossroads of Los Angeles.

In the final essay, Esra Akcan documents the largely Turkish Kreuzberg district of Berlin in the 1970s, which came to be known as Berlin's Harlem. Heavily bombed during World War II, Kreuzberg was not rebuilt until the IBA began to rehabilitate some buildings and build new ones between 1979-1987. Despite the large presence of Turkish 'guest workers' and their families, none of the briefs consigned to the internationally famed architects invited to participate in the IBA acknowledged this group, while the Senate enacted laws to prevent more than $10 \%$ of buildings in three major areas of Berlin (Kreuzberg, Wedding, and Tiergarten) being rented to non-citizens. Additional regulations limited the number of large units, big enough for the typically large Turkish families, that could be included in any project to 5 or $10 \%$. Fortunately, the architects involved in rehabilitation subverted the Senate dictates in ingenious ways, including unit by unit collaborations with residents.

This long review takes account of the enormous intellectual labor undertaken by these authors to root out and expose the often concealed or obscured racism by isolating specific cases and demonstrating the art of such interrogations elsewhere. My review does not do full justice to the painstaking and extraordinarily original approaches pursued by Davis, Cheng, Wilson, Carranza, Herscher, and the others. These studies appear at an opportune moment, when the desire to understand the mechanisms 
of racism and exclusion in architecture has finally emerged. The two books are extraordinary achievements of enduring significance, and the authors are to be congratulated for jobs well done.

Diane Ghirardo is a Professor of History at the University of Southern California. She is the author of numerous articles and presentations, in particular Building New Communities, New Deal America and Fascist Italy (1989); Architecture after Modernism (1996); Italy. Modern Architecture (2013); Aldo Rossi and the Spirit of Modern Architecture (2019); Lucretia Borgia d'Este. Le lettere 1494-1519 (2020). E-mail: ghirardo@usc.edu 